\title{
STRATEGI KOMUNIKASI RADIO dBs 101,9 FM BANJARMASIN DALAM MENARIK PARTISIPASI PENDENGAR PADA PROGRAM REQUEST LAGU Aisya Fitria Hasan ${ }^{1}$, Sarwani ${ }^{2}$, Muhammad Muthahhari Ramadhani ${ }^{3}$ \\ Universitas Lambung Mangkurat Banjarmasin \\ Email : muthahhari.ramadhani@ulm.ac.id
}

\begin{abstract}
ABSTRAK
Radio merupakan salah satu media massa yang masih bertahan hingga saat ini, namun radio perlahan mulai ditinggalkan sebagai media hiburan karena munculnya media baru yaitu platform streaming music online. Sehingga, radio harus memiliki strategi komunikasi yang tepat dalam mempertahankan pendengarnya. Penelitian ini bertujuan untuk mengetahui strategi komunikasi radio dBs 101,9 FM dalam menarik partisipasi pendengar pada program request lagu serta mengetahui faktor pendukung dan penghambat radio dBs 101,9 FM dalam menarik partisipasi pendengar pada program request lagu. Penelitian ini menggunakan pendekatan kualitatif deskriptif dengan menggunakan teori Uses and Gratification dan model Komunikasi Melvin De Fleur. Hasil penelitian menunjukkan strategi komunikasi radio dBs 101,9 FM dalam menarik partisipasi pendengar pada program request lagu, yaitu mengenal khalayak, menyusun pesan, menetapkan metode, dan pemilihan media. Faktor pendukung: jenis musik bervariasi, media yang beragam, lagu ter-update, perkembangan digital dan internet, promosi terus-menerus, dan kualifikasi penyiar. Faktor penghambat: faktor internal dari diri penyiar yaitu suasana hati, faktor eksternal berupa ganguan teknis, hari libur, cuaca buruk, persaingan radio dan kemunculan platform streaming music online.
\end{abstract}

Kata Kunci: Strategi Komunikasi;Penyiar;Program Request Lagu; Radio dBs 101,9 FM .

\section{PENDAHULUAN}

Musik telah menjadi bagian dari kehidupan yang tidak dapat dipisahkan dan selalu hadir menemani keseharian masyarakat. Musik menjadi pilihan terbaik yang mewakili perasaan yang sedang dirasakan. Musik mampu mewakili dengan baik ungkapan yang tidak bisa dikatakan secara langsung melalui verbal. Itulah mengapa ketika mendengarkan musik orang akan merasakan kelegaan dan merasa lebih baik.

John M. Ortiz dalam Rosyidi (2008:3) menyebutkan ada beberapa manfaat yang dapat dirasakan ketika mendengarkan musik yakni: menjaga konsentrasi, membuat pikiran tenang, meningkatkan kewaspadaan, dan meminimalisir suara-suara eksternal yang membuat hilang fokus. Selain itu, musik juga menjadi sarana hiburan bagi mayoritas masyarakat. Fungsi hiburan didapatkan melalui media elektronik seperti televisi dan radio.

Menurut hasil survei yang dilakukan oleh IFPI bertajuk “Music Listening 2019”, dengan responden berusia 16-64 tahun dan mengambil data dari 21 negara, dirilis pada 24 September 2019 melalui laman resminya menyebutkan bahwa responden menghabiskan 18 jam per minggu untuk mendengarkan musik.

Perkembangan teknologi di era digital sekarang ini berkembang dengan sangat pesat. Kemudahan senantiasa hadir menyeimbangkan kehidupan yang semakin kompleks. Dengan peranan new media, khalayak mempunyai banyak pilihan dalam aspek mendengarkan musik. Kemunculan berbagai platform digital music streaming online dengan menawarkan kemudahan dalam aktivitas mendengarkan musik. Layanan pemutar musik online adalah suatu teknologi yang berfungsi untuk memutar musik secara online. Seperti Joox, Spotify, Shazam, Deezer, Apple Music, Youtube Music, dan lain-lain.

DailySocial melakukan survei pada Februari 2018 bekerjasama JakPat Mobile Survey Platform, dengan total 1955 responden tersebar di seluruh wilayah Indonesia. Survei ini bertujuan untuk mengetahui pola kebiasaan dan penerimaan khalayak terhadap layanan streaming musik. Hasil temuan yang dirilis pada 3 Maret 2018 di laman dailysocial.id adalah hampir $90 \%$ dari total responden mengaku mendengarkan musik melalui aplikasi music streaming online.

Beragamnya aplikasi music streaming online membuat media konvensional perlahan mulai tergantikan dan ditinggalkan. Hal tersebut tentunya membuat media konvensional seperti radio harus memiliki strategi komunikasi yang tepat dalam mempertahankan fungsinya dan meningkatkan pendengar. Ditengah maraknya kemunculan media baru menawarkan berbagai kemudahan dan fiturfitur menarik, radio perlahan mulai kehilangan pendengarnya. 
Radio dBs 101,9 FM dipilih menjadi objek penelitian berdasarkan beberapa alasan yang ditemukan pada saat peneliti melakukan observasi. Radio dBs 101,9 FM memiliki total 39 program siaran dengan format yang beragam. Sedangkan, jumlah penyiar radio dBs 101,9 FM saat ini adalah 20 orang. Dengan jumlah tersebut radio dBs 101,9 FM dapat dikatakan satu-satunya radio yang memiliki jumlah program dan penyiar terbanyak di Banjarmasin. Selain itu, dibandingkan dengan beberapa radio lain di Banjarmasin, radio $\mathrm{dBs}$ 101,9 FM memiliki cakupan jenis musik yang luas dan bervariasi tidak hanya memutarkan lagu-lagu dari penyanyi Indonesia, namun juga mancanegara hingga Asia Timur. Hal tersebut bertujuan untuk menyediakan wadah bagi pendengar dalam menikmati berbagai aliran musik, sehingga pendengar bebas memilih program berdasarkan aliran musik yang mereka sukai.

Radio memiliki karakteristik auditory, radio adalah suara. Suara yang muncul disiaran radio hanya kata-kata dan musik (lagu). Karena itulah radio identik dan berkaitan erat dengan musik. Berbagai macam kategori program acara yang dibuat untuk menarik minat dengar khalayak. Salah satunya adalah program musik. Tidak dapat dipungkiri musik menjadi kebutuhan hiburan bagi banyak orang, media massa termasuk radio seringkali memanfaatkan peluang ini. Hal itulah yang kemudian menjadi dorongan bagi pengelola radio untuk berusaha membuat program-program yang sekiranya dapat menarik perhatian pendengar. Keberhasilan suatu program acara radio dapat diukur dari seberapa besar respon positif yang didapat dari pendengar sehingga program tersebut dianggap telah diterima oleh khalayak.

Program request lagu sangat populer dan berdaya tarik tinggi bagi pendengar. Di mana pendengar dapat secara bebas meminta sebuah lagu yang ingin ia dengarkan untuk diputar sekaligus kirim-kirim salam baik melalui telepon interaktif atau media sosial. Berbeda dengan program lainnya, dalam program request lagu pendengar harus memberikan feedback agar program tersebut berjalan sesuai dengan tujuannya. Pada program request lagu komunikasi penyiar sifatnya adalah mengajak pendengar untuk bergabung menjadi bagian dari program tersebut berupa timbal balik dengan berpartisipasi untuk meminta lagu dan kirim salam.

Walaupun program request menjadi andalan di radio karena dapat menarik pendengar, diakuinya jika partisipasi pendengar kadangkala rendah untuk berpartisipasi dalam program request lagu. Itulah yang menjadi tantangan bagi seorang penyiar untuk secara maksimal menerapkan strategi komunikasi yang telah dirancang pihak radio agar dapat meningkatkan partisipasi pendengar.

Strategi komunikasi sangat diperlukan dalam stasiun radio, sebab radio memiliki fungsi untuk memenuhi kebutuhan khalayak mulai dari informasi sampai hiburan. Melalui strategi komunikasi yang diterapkan radio dBs 101,9 FM, diharapkan mampu mencapai tujuan. Maka, penting merencanakan langkah strategis untuk diterapkan agar kegiatan komunikasi dapat menjangkau sasaran dengan lebih efektif. Dengan hasil yang diharapkan adalah pendengar terdorong untuk berpartisipasi pada program request lagu.

Pentingnya meneliti strategi komunikasi radio adalah untuk mengetahui cara atau langkah yang dilakukan oleh radio dalam menarik partisipasi pendengar pada program request lagu. Seperti yang telah dijelaskan sebelumnya, dalam program request lagu mengharuskan adanya partisipasi dari pendengarnya agar program tersebut berjalan. Sehingga, hal ini menjadi tantangan bagi radio dBs 101,9 FM dalam menentukan strategi komunikasi yang tepat untuk mencapai tujuan program request lagu yakni, membuat pendengar berpartisipasi dalam program acara dengan mengirim tanggapan berupa permintaan sebuah lagu untuk diputarkan.

\section{KAJIAN TEORI}

Rogers dalam Cangara (2016:22) mengungkapkan bahwa definisi komunikasi adalah proses pengalihan ide dari sumber kepada penerima dengan tujuan untuk mengubah tingkah laku. Sementara itu, Hovland dalam Azmi (2014:89) berpendapat bahwa komunikasi adalah upaya yang terstuktur dalam merencanakan secara jelas dasardasar proses komunikasi dan pembentukan sikap atau pandangan. Hovland menyakini perilaku manusia dapat diubah melalui komunikasi.

\section{Komunikasi Massa}

Berdasarkan pernyataan dari Bittner dalam Ardianto, Komala dan Karlinah (92015:3) menjelaskan definisi komunikasi massa ialah pesan yang disampaikan melalui perantara media massa kepada orang banyak. Sementara itu, Nurudin (2011:1-2) menjelaskan, komunikasi massa sebagai komunikasi yang melalui media massa (media cetak dan elektronik). 


\section{Radio}

Dominick dalam Ardianto, Komala dan Karlinah (2015:123) mengungkapkan bahwa media massa tertua adalah radio dan bersifat fleksibel. Dari awal kemunculannya hingga sekarang, radio mampu bersaing dengan media lainnya seperti televisi, bioskop, kaset, dan sebagainya. Dengan mengikuti perkembangan teknologi, radio beradaptasi untuk membangun hubungan timbal balik dan melengkapi media lainnya.

\section{Penyiar}

Definisi penyiar menurut Yulia (2010:17) adalah seseorang yang dapat menyampaikan pesan berupa gagasan, konsep, atau ide, dan ia juga bertanggung jawab memandu program dalam siaran radio dengan lancar.

Suara adalah aset bagi penyiar. Selain harus pandai bicara dan ramah, Romli (2009: 38-40) menyebutkan penyiar dituntut memenuhi ketentuan lain untuk menunjang profesionalitas dalam bekerja. Berikut kualifikasi jika ingin menjadi penyiar, yakni:

a. Announcer's Skill

Karena radio mengandalkan medium suara dalam menyampaikan pesannya, maka keterampilan utama penyiar yakni lancar berbicara di depan microphone atau di dalam ruang siar. Antara satu radio dan lainnya, mempunyai kriteria tersendiri dalam menilai kemampuan penyiar yang akan direkrut.

b. Adaptability

Penyiar harus menyesuaikan diri dengan tim, perubahan program dan jadwal siaran.

c. Berwawasan Luas

Untuk menghindari siaran yang tidak berisi, penyiar harus memiliki wawasan yang luas dengan banyak membaca agar mengetahui perkembangan dunia atau kejadian disekitar dan selalu up to date mengenai informasi terkini.

d. Sense of Music

Radio sangat identik dengan musik. Itulah yang membuat penyiar harus memiliki segudang pengetahuan mengenai lagu dan penyanyi baik dalam maupun luar negeri.

e. Sense of Humor

Penyiar yang humoris biasanya disukai pendengar karena mampu menghibur dengan candaan dan guyonan yang dapat mencairkan suasana sehingga siarannya tidak terkesan kaku.

\section{f. Jiwa Entertrainer}

Salah satu fungsi radio adalah hiburan, sehingga penyiar harus memiliki bakat entertaint. Dalam kondisi apapun penyiar harus memberikan kesan fresh and cheerful agar dapat memberikan keceriaan kepada pendengarnya.

g. Good Looking

Konteks good looking yang dimaksud tidak melulu soal wajah yang tampan atau cantik, namun lebih sikap dan penampilan seperti ramah, murah senyum, bersih, dan berpakaian rapi serta sopan.

\section{Program Siaran Radio}

Bouthm Norgafh Weiss dalam Christiany (2016:49) mengungkapkan bahwa istilah programming adalah membuat program atau acara radio. Tujuan dari programming yakni untuk membentuk kepribadian stasiun radio, yang merupakan hal terpenting bagi sebuah radio. Setiap program yang dibuat untuk disiarkan memiliki visi, misi, target pendengar, isi siaran, format musik, gaya siaran, bahasa siaran, dan durasi yang berbeda-beda.

Romli (2009:74-80) menyebutkan macammacam program siaran radio. Adapun beberapa kategori program yang umumnya terdapat pada stasiun radio, antara lain sebagai berikut:

a. Music Program

Program utama radio adalah acara musik.

Namun, hal itu tidak berlaku pada radio berita yang tidak memiliki program untuk pemutaran lagu. Music Program terdiri dari request, non-request dan tangga lagu.

b. News Program

Program berita merupakan program yang berisikan informasi terkini mengenai berita terhangat dan isu-isu teraktual yang beredar dikalangan masyarakat.

c. Siaran Talkshow

Program Talkshow atau chat show adalah program bincang-bincang, obrolan atau dialog interaktif. Program ini menghadirkan narasumber untuk diajak berdialog sesuai dengan materi yang akan dibawakan pada saat itu.

d. Program Dakwah

Program siaran dakwah umumnya disiarkan pada waktu subuh sekitar pukul 05:00-06:00 dan menjelang adzan magrib. Dapat berbentuk ceramah dari ustadz, murottal, dan 
memutarkan lagu-lagu religi atau lagu-lagu mancanegara "Barat" bertempo slow.

\section{Strategi Komunikasi}

Strategi komunikasi adalah sebuah perencanaan yang melibatkan komunikasi didalamnya. Strategi komunikasi kerap dikaitkan dengan organisasi komunikasi, yang menjadi titik utama dari strategi komunikasi adalah bentuk langkah-langkah strategis yang direncanakan dan kemudian digunakan suatu organisasi, dengan demikian kegiatan komunikasi tersebut dapat menjangkau sasaran komunikasi secara lebih efektif.

Strategi komunikasi dapat mempengaruhi keefektifan dalam proses komunikasi. Melakukan kegiatan komunikasi tanpa mempertimbangkan strategi komunikasi yang tepat dapat menimbulkan pengaruh negatif yang akan merugikan. Pandangan lain mengenai definisi strategi komunikasi dinyatakan oleh Anwar Arifin dalam Suryadi (2018:5) yang menyebut, bahwa strategi merupakan ketentuan kondisional mengenai langkah-langkah yang akan dilaksanakan untuk mencapai tujuan. Sehingga, dalam menentukan strategi komunikasi, maka dilihat dari situasi atau kondisi yang mungkin dialami. Penerapan strategi komunikasi dilakukan dengan menggunakan langkah-langkah komunikasi untuk mendorong khalayak melakukan perubahan yang diinginkan komunikator dengan lancar.

Fajar (2009:183) menerangkan bahwa untuk menyusun strategi komunikasi ada langkahlangkah yang dapat diterapkan, diantaranya:

1. Mengenal Khalayak

Untuk menciptakan strategi komunikasi yang efektif, hal pertama yang harus dilakukan adalah mengenal khalayak. Hal ini dilihat dari tujuan komunikasi, apakah hanya agar komunikan mengetahui sebuah informasi (metode informatif) atau merangsang komunikan agar memberikan tanggapan dan tindakan (metode persuasif). Hal yang perlu dicermati dalam langkah ini adalah kerangka referensi, kondisi serta situasi khalayak.

2. Menyusun Pesan

Setelah komunikator mengenal siapa komunikannya, langkah kedua dalam strategi komunikasi adalah menyusun pesan. Menentukan tema dan materi adalah bagian dari menyusun pesan. Agar dapat mempengaruhi khalayak melalui pesan maka komunikator harus mampu menumbuhkan perhatian. Hal ini sesuai dengan AA procedure atau from Attention to Action procedure yang berarti menumbuhkan perhatian (Attention) dan kemudian mendorong khalayak untuk melakukan tindakan (Action) sesuai dengan tujuan yang diinginkan.

3. Menetapkan Metode

Metode penyampaian dapat dipandang melalui cara pelaksanaannya dan isinya. Menurut cara pelaksanaanya, dapat direalisasikan melalui metode redundancy (repetition) dan canalizing. Sementara itu, berdasarkan bentuk isinya terbagi menjadi metode informatif, persuasif, dan edukatif.

4. Pemilihan Media Komunikasi

Media komunikasi berkembang dengan pesat dan cepat, khalayak dapat dengan mudah dan secara bebas memilih media yang sesuai kehendak dan dapat memenuhi kebutuhannya. Bukan hal baru, jika proses komunikasi berlangsung menggunakan beberapa media sekaligus, didasari pada tujuan, informasi yang disampaikan dan teknik yang dipakai, karena setiap media memiliki karakteristik, kelebihan dan kelemahan masing-masing, sehingga hal tersebut dapat dimanfaatkan secara optimal.

\section{Uses and Gratifications}

Teori Uses and Gratifications dirumuskan Herbert Blumer, Elihu Katz dan Michael Gurevitch (1974). Teori Uses and Gratifications menyatakan bahwa khalayaklah yang menentukan apakah informasi yang beredar di media mereka konsumsi atau abaikan. Jika informasi tersebut tidak dibutuhkan oleh khalayak maka informasi tersebut tidak akan mempengaruhi apapun terhadap khalayak tersebut. Dalam teori ini khalayak berperan aktif untuk menggunakan media sebagai sarana pemenuhan kebutuhannya. Sebab, fokus perhatian pada teori ini adalah penggunaan (uses) media untuk mendapatkan kepuasan (gratifications) terhadap kebutuhan khalayak (Nurudin, 2011:191-192).

\section{Model Melvin De Fleur}

Penelitian ini menggunakan model komunikasi massa Melvin De Fleur. Penggunaan model dalam sebuah penelitian bertujuan untuk memberikan gambaran yang sistematis sehingga dapat menunjukkan kaitan antar elemen-elemen yang terikat. Menurut model Melvin De Fleur 
proses komunikasi membutuhkan tanggapan dari khalayak agar menjadi lebih efektif. Dengan menambahkan umpan balik dalam kegiatan komunikasi maka akan memberikan keuntungan bagi sumber, sebab dapat diketahui bagaimana khalayak menanggapinya. Nurudin (2011:147) menyebut dalam model ini terdapat beberapa elemen, diantaranya adalah sumber, pemancar, saluran, penerima, tujuan, gangguan, dan umpan balik.

\section{METODE PENELITIAN}

Penelitian ini menggunakan pendekatan kualitatif atau disebut juga naturalistik karena penelitiannya dilakukan pada kondisi alamiah dengan tipe penelitian deskriptif. Penelitian deskriptif dijabarkan dengan kata-kata berdasarkan pernyataan informan, secara apa adanya berdasarkan pertanyaan dari peneliti, selanjutnya dianalisis menggunakan kata-kata mengenai apa yang menjadi latar belakang dari perilaku informan, direduksi, ditriangulasi, disimpulkan dan diverifikasi (Usman dan Akbar, 2017:189).

Objek pada penelitian ini adalah strategi komunikasi yang digunakan oleh penyiar di radio dBs 101,9 FM dalam menarik partisipasi pendengar pada program request lagu. Pengumpulan data penelitian ini menggunakan teknik wawancara, observasi dan dokumentasi. Informan terbagi menjadi informan kunci yaitu, penyiar program request lagu dan informan pendukungnya ialah owner, station manager, music director, koordinator program dan pendengar.

Model Miles dan Huberman dipilih sebagai teknik analisis data dipenelitian ini terbagi menjadi tiga alur kegiatan yaitu reduksi data, penyajian data dan penarikan kesimpulan atau verifikasi (Sugiyono, 2012:246). Penelitian ini berlokasi di Radio dBs 101,9 FM yang berada di jalan Dahlia No. 35 Banjarmasin, dan dilaksanakan mulai bulan Januari hingga Maret 2021.

\section{HASIL DAN PEMBAHASAN}

Sebagai radio yang telah beroperasi lebih dari 30 tahun, tentunya radio dBs 101,9 FM telah mengalami naik turun minat pendengar seiring perkembangan teknologi dengan kemunculan media baru dan memiliki pengalaman dalam menghadapi hal-hal yang merugikan seperti antusiasme pendengar menurun atau partisipasi pendengar rendah dalam suatu program. Oleh karena itu, untuk mengantisipasi hal tersebut radio
dBs 101,9 FM berupaya merancang dan menerapkan strategi komunikasi yang tepat dalam menarik perhatian pendengar agar tertarik berpartisipasi pada program request lagu.

\section{Mengenal Khalayak}

Langkah pertama adalah mengetahui pendengar yang menjadi sasaran komunikasi. Hal ini dilihat dari tujuan komunikasi, apakah hanya untuk menginformasikan pesan atau mendorong komunikan untuk melakukan tindakan sesuai keinginan komunikator (Fajar, 2009:183). Dengan mengetahui khalayak yang menjadi pendengar pada program request lagu yang dipandu, informan menyebutkan akan lebih mudah dalam melalukan pendekatan secara emosional untuk membangun keakraban antara pendengar dan penyiar, sehingga komunikasi berjalan dengan baik. Selain itu, pentingnya mengenal pendengar adalah untuk menyesuaikan pembawaan penyiar dengan karakter dari pendengar tersebut. Pihak radio dBs 101,9 FM beranggapan bahwa dengan mengetahui pendengar, maka penyiar akan lebih memahami karakter, kesukaan, minat dan kebutuhan pendengarnya.

\section{Menyusun Pesan}

Untuk memudahkan penyiar dalam memberikan pesan pada program baik request lagu atau lainnya, informan menyatakan bahwa menyusun pesan diawali dengan menentukan tema dan materi saat rapat pada proses pembuatan program (Fajar, 2009:183). Sehingga, ketika tema utama sudah ditentukan, maka akan memudahkan penyiar dalam mencari informasi dan materi yang sesuai dengan tema tersebut untuk disampaikan kepada pendengar. Menurut informan, materi utama program request lagu adalah suguhan lagulagu dan informasi terkini sesuai dengan tema program yang dibawakan yang dinilai berguna bagi pendengarnya dan tentunya informasi yang disampaikan terjamin kebenarannya, sehingga tidak menyebarkan berita palsu kepada pendengar.

\section{Menentukan Metode Komunikasi}

Pada program request lagu tidak ada pesan tertentu yang harus dibacakan untuk pendengar, sehingga penyiar dapat dengan leluasa membahas apapun saat siaran. Penyiar menerapkan metode informatif dalam siarannya, di mana ia menyampaikan informasi terkini yang relevan dengan format program request lagu yang ia bawakan saat itu. Metode persuasif digunakan untuk mengajak pendengar berpartisipasi dengan menyampaikan kalimat-kalimat yang bersifat mengajak. 
Informan lainnya mengaku bahwa persuasi adalah hal yang terus menerus ia lakukan secara berulang-ulang bertujuan untuk membangkitkan perhatian pendengar. Di mana ia berusaha membujuk pada pendengarnya bergabung untuk menjadi partisipan. Kalimat ajakan tersebut menjadi standarisasi yang berfungsi untuk memberitahukan dan mengingatkan pendengar bahwa program yang dibawakan adalah program yang dapat menerima request lagu pilihan dari pendengar serta pendengar dapat mengirimkan salam baik secara langsung atau dibacakan oleh penyiar yang bersangkutan.

\section{Pemilihan Media Komunikasi}

Media komunikasi berkembang dengan pesat dan cepat, khalayak dapat dengan mudah dan bebas memilih menggunakan media. Menurut informan media sosial merupakan media yang hampir dimiliki semua orang. Sehingga, radio dBs 101,9 FM juga ikut mengandalkan media sosial sebagai perantara media komunikasi antara pendengar dengan penyiar. Dengan menggunakan fitur-fitur yang tersedia, seperti live instagram yang menjadi sebuah cara dalam menarik perhatian pendengar. Tiap media komunikasi memiliki warnanya masing-masing.

Pendengar memilih media komunikasi berdasarkan beberapa faktor seperti kemudahan akses, fitur-fitur menarik, bebas biaya dan sebagainya. Beragamnya saluran komunikasi dapat membuat jangkauan lebih lebar sehingga berpotensi menambah jumlah pendengar dan membuka jalan bagi pendengar yang ingin berpartisipasi pada program request lagu. Dengan membuka banyak platform maka akan memudahkan pendengar dalam mengakses dan berinteraksi dengan penyiar secara langsung, sehingga akan terjalin komunikasi dua arah dan hubungan timbal balik diantara keduanya. Diketahui radio dBs 101,9 FM memiliki beberapa media komunikasi seperti telepon interaktif, layanan streaming, dan media sosial seperti instagram, facebook, dan whatsapp.

\section{Faktor Pendukung}

Terdapat beberapa faktor pendukung dalam menarik partisipasi pendengar pada program request lagu, pertama jenis musik yang bervariasi. Program utama radio adalah acara musik (Romli, 2009:74-80). Radio dBs 101,9 FM memiliki jumlah program request lagu terbanyak, yakni 12 program. Di mana tiap program tersebut memiliki format musik yang berbeda-beda. Melalui hal ini dapat diketahui bahwa radio dBs 101,9 FM memberikan kesempatan yang sama kepada seluruh pendengarnya untuk dapat mendengarkan lagu-lagu favorit mereka dengan berpartisipasi pada program request lagu sesuai dengan jenis atau aliran musik yang mereka sukai. Faktor pendukung berikutnya, sekaligus menjadi keunggulan dari radio dBs 101,9 FM yaitu lagu-lagu ter-update. Telah dibahas sebelumnya bahwa radio dBs 101,9 FM berupaya menyajikan lagu-lagu terkini, sesuai dengan tujuan dan tagline mereka.

Radio dBs 101,9 FM menyediakan beberapa media komunikasi untuk memudahkan pendengarnya dalam berinteraksi dengan penyiar pada program request lagu, dengan memiliki saluran komunikasi yang beragam tentunya menjadi faktor pendukung lainnya dalam menarik partisipasi pendengar terutama pada program request lagu. Beragamnya saluran komunikasi yang dibuat oleh radio dBs 101,9 FM adalah untuk menyesuaikan kondisi dari pendengarnya, sehingga mereka dapat memilih media mana yang akan mereka gunakan sebagai alat komunikasi untuk berpartisipasi.

Perkembangan digital dan internet menguntungkan radio dBs 101,9 FM menggunakan beberapa media sekaligus, dan berkonvergensi secara digital sehingga dapat didengarkan dengan terhubung ke internet melalui layanan streaming dan aplikasi yang dapat diunduh melalui gawai pendengar masing-masing. Didukung dengan lebihan radio yakni tanpa batas dengan terhubung ke internet tentunya akan memudahkan pendengar mengakses radio dBs 101,9 FM tanpa terbatas ruang ataupun waktu (Romli, 2009:19). Sehingga, cakupan yang diperoleh lebih luas bahkan diluar kota Banjarmasin.

Faktor pendukung selanjutnya dalam menarik partisipasi pendengar pada program request lagu menurut informan adalah gencarnya promosi yang dilakukan baik oleh pihak radio dBs 101,9 FM maupun pendengarnya. Berbagai metode dilakukan untuk memperomosikan program request lagu di radio dBs 101,9 FM. Salah satunya adala promosi dari mulut ke mulut oleh pendengarnya yang mengajak untuk mendengarkan dan berpartisipasi. Tak hanya itu, penyiar 'pun harus turut andil dalam mempromosikan program yang ia bawakan bahkan harus melakukan usaha lebih.

Faktor pendukung terakhir datang dari pribadi penyiar berupa keterampilan yang dimiliki penyiar. Hal ini disampaikan oleh informan yang 
mengungkapkan bahwa modal untuk menjadi seorang penyiar adalah pengetahuan dan wawasan luas. Penyiar adalah sumber informasi bagi pendengarnya.

Sense of humor termasuk kualifikasi penyiar, di mana penyiar yang menyenangkan tentunya dapat memenangkan hati pendengarnya dan membuat pendengar merasa enjoy ketika mendengarkan atau berkomunikasi dengan penyiar tersebut. Dalam membawakan program request lagu salah satu hal terpenting adalah pengetahuan penyiar mengenai musik, hal ini berkaitan dengan radio identik dengan musik (Romli, 2009:39). Sebagai pemandu acara penyiar radio harus belajar menumbuhkan jiwa entertrainer didalam dirinya. Menurut Romli (2009: 39) salah satu fungsi radio adalah hiburan, sehingga penyiar harus memiliki bakat entertaint.

Karena radio adalah media massa yang menggunakan medium suara dalam proses komunikasinya. Pendengar hanya mampu menangkap seluruh informasi melalui suara dari penyiar. Sesuai dengan pernyataan Ben G. Henneke dalam Romli (2009:38), faktor pendukung lainnya menurut informan sebagai penyiar program request lagu adalah kontrol suara, seperti tempo, power, artikulasi dan intonasi.

\section{Faktor Penghambat}

Diakui oleh informan, faktor penghambat internal berasal dari diri penyiar yaitu, suasana hati penyiar. Shanon dan Weaver dalam Cangara (2016:167) berpendapat hal tersebut masuk dalam rintangan psikologis. Penyiar selalu dituntut untuk profesional dalam menghiburkan para pendengarnya. Namun, ada kalanya penyiar merasa tidak dalam kondisi yang baik, sehingga hal tersebut mempengaruhi performa mereka dalam memandu sebuah program acara saat siaran.

Faktor penghambat eksternal dalam menarik partisipasi pendengar pada program request lagu yang pertama adalah gangguan teknis. Menurut Shanon dan Weaver dalam Cangara (2016:167) gangguan teknis terjadi ketika alat komunikasi yang digunakan mengalami gangguan, sehingga informasi yang disalurkan tidak tersampaikan dengan baik. Misalnya microphone yang terkadang suara yang muncul tidak stabil, entah naik-turun atau tidak terdengar dengan jelas.

Pada model komunikasi Melvin De Fleur ditegaskan fakta bahwa gangguan tidak dapat dihindari dalam kegiatan komunikasi. Gangguan berpeluang terjadi pada semua elemen yang ada, baik dari sumber, saluran/media, pemancar, penerima, tujuan maupun umpan balik (Ardianto, Komala dan Karlinah, 2015:82).

Selain teknis, persaingan media radio di Banjarmasin saat ini sangat ketat, ditambah dengan kemunculan berbagai platform musik memudahkan pendengarnya mengakses dan keunggulan lainnya ditambah dengan perbaruan fitur-fitur yang mengikuti kesukaan penikmat musik menyebabkan persaingan antar media yang membuat khalayak menjadi terbagi-bagi. Fenomena diatas dapat dijelaskan melalui sebuah teori komunikasi yaitu Uses and Gratifications. Dalam teori ini khalayak berperan aktif untuk menggunakan media sebagai sarana pemenuhan kebutuhannya. Tidak dapat dicegah bahwa khalayak akan tertarik dengan halhal yang dapat memudahkan mereka dalam memenuhi kebutuhan informasi dan hiburan ditengah kehidupan yang kompleks saat ini.

Hari libur juga termasuk faktor penghambat. Biasanya perayaan hari-hari besar membuat para pendengar tidak mendengarkan radio, karena menikmati kebersamaan bersama keluarga dan orang-orang terkasih dalam menyambut perayaan tersebut. Selain itu, saat libur panjang mayoritas orang-orang akan memanfaatkannya untuk berpergian, berekreasi, atau melakukan hal lain yang tidak sempat dilakukan ketika hari biasa. Oleh karena itu, dapat diasumsikan bahwa dengan kondisi tersebut pendengar tidak berpartisipasi pada program request lagu seperti biasanya.

Kondisi cuaca yang buruk menjadi salah satu hal yang dapat menghambat dalam menarik partisipasi pendengar pada program request lagu. Terutama menghambat penyiar untuk siaran, entah karena terjebak hujan dan menyebabkan siaran delay, atau kondisi penyiar sedang tidak enak badan dan sebagainya. Tidak hanya mempengaruhi para penyiar, namun juga pendengar yang mendengarkan radio $\mathrm{dBs}$ 101,9 FM melalui radio analog akan mempengaruhi suara yang dihasilkan menjadi tidak jernih.

\section{KESIMPULAN}

Strategi komunikasi yang digunakan radio dBs 101,9 FM dalam menarik partisipasi pendengar pada program request lagu yang pertama adalah mengenal khalayak, yang meliputi mengetahui kondisi, karakter, kebutuhan, minat dan ketertarikan pendengar. Mengenal khalayak adalah salah satu faktor untuk radio dBs 101,9 FM dalam 
membuat program baru untuk memudahkan pihak radio memperkirakan program seperti apa yang disukai pendengar atau informasi apa yang dibutuhkan pendengar.

Menyusun pesan terdiri dari menentukan tema dan materi yang telah ditentukan pada saat proses pembuatan program. Dalam program request lagu, tema yang dipilih berbeda, dan materinya adalah suguhan lagu-lagu sesuai format program.

Dalam langkah strategi menetapkan metode komunikasi, radio dBs 101,9 FM menggunakan metode persuasif dan metode informatif. Kemaksimalan penerapan strategi ini tergantung pada penyiar yang memandu program tersebut, apakah ingin menggunakan satu metode komunikasi saja yaitu metode persuasif atau didukung dengan metode lainnya.

Strategi terakhir adalah pemilihan media komunikasi. Radio dBs 101,9 FM menggunakan berbagai media komunikasi untuk mengoptimalkan penyebaran informasi, menjangkau lebih luas khalayak, dan memudahkan pendengar mengakses radio dBs 101,9 FM. Strategi ini dilakukan secara maksimal, karena dapat mempengaruhi jumlah partisipasi pendengar.

Faktor pendukungnya adalah pilihan jenis musik bervariasi, media komunikasi yang beragam, lagu-lagu terbaru, perkembangan digital dan internet, promosi terus-menerus, dan kualifikasi penyiar. Faktor penghambat yakni, faktor internal datang dari dalam diri penyiar, suasana hati. Sedangkan, faktor eksternal berupa ganguan teknis seperti microphone rusak atau pemancar gangguan, hari besar atau libur panjang, cuaca buruk, persaingan antar radio dan kemunculan platform music streaming online.

\section{SARAN}

1. Mempertahankan strategi komunikasi yang saat ini diterapkan dan memperbarui komponen perangkat siaran untuk menunjang kelancaran aktivitas siaran.

2. Penyiar radio dBs 101,9 FM diharapkan dapat mengendalikan suasana hati pada saat siaran dengan cara perbanyak latihan dan belajar penguasaan diri.

3. Sebagai radio swasta tertua di Banjarmasin, radio dBs 101,9 FM dapat menjadi pionir bagi radio lainnya dalam menyuguhkan halhal yang dapat meningkatkan minat dengar khalayak.
4. Melakukan survei kepada pendengar untuk mengetahui secara lebih jelas mengenai tanggapan mereka tentang radio yang diteliti dan mengetahui apa yang dibutuhkan oleh pendengar pada sebuah program.

5. Mengkaji aspek lain dari sudut pandang yang berbeda dalam mempertahankan eksistensi radio dan mengembangkan program-program yang lebih kreatif sehingga dapat menarik partisipasi pendengar.

\section{REFERENSI}

Ardianto, Elvinaro, Lukita Komala, dan Siti Karlinah. (2015). Komunikasi Massa Suatu Pengantar. Bandung: Simbiosa Rekatama Media.

Azmi, Khaerul. (2014). Filsafat Ilmu Komunikasi. Tangerang: Indigo Media.

Cangara, Hafied. (2016). Pengantar Ilmu Komunikasi. Jakarta: PT RajaGrafindo Persada.

Juditha, Christiany. (2016). Strategi Programming RRI Jayapura \& Merauke dalam Penguatan NKRI di Wilayah Perbatasan. Jurnal Penelitian Komunikasi dan Opini Publik. Vol. 20. No. 1. 45-62.

Nurudin. (2011). Pengantar Komunikasi Massa. Jakarta: PT RajaGrafindo Persada.

Romli, Asep Syamsul M. (2009). Basic Announcing: Dasar-dasar Siaran Radio. Bandung: Nuansa.

Rosyidi, Fathu Rahman. (2008). Pengaruh Musik Terhadap Kenyamanan Membaca Pengguna Perpustakaan Fakultas Bahasa dan Seni Universitas Negeri Yogyakarta. Skripsi. Universitas Islam Negeri Sunan Kalijaga. Yogyakarta.

Sugiyono. (2012). Metode Penelitian Kuantitatif, Kualitatiffan R\&D. Bandung: Alfabeta.

Suryadi, Edi. (2018). Strategi Komunikasi: Sebuah Analisis Teori dan Praktis di Era Global. Bandung: PT Remaja Rosdakarya.

Usman, Husaini, dan Purnomo Setiady Akbar. (2017). Metodologi Penelitian Sosial, Edisi Ketiga. Jakarta: PT Bumi Aksara.

Yulia, Winda. (2010). Andai Aku Jadi Penyiar. Yogyakarta: Andi.

\section{Sumber Lain}

Dailysocial.id. (2018, 3 Maret). Survei Layanan Streaming Musik 2018. Diakses pada 22 Oktober 2020, dari 
Aisya Fitria Hasan, Sarwani, dan Muhamamd Muthahhari Ramadhani

MUTAKALLIMIN; Jurnal Ilmu Komunikasi

Vol 4 No 1 Mei 2021

https://dailysocial.id/post/laporan-

dailysocial-survei-layanan-streaming-

musik-2018

IFPI. (2019, 24 September). Music Listening 2019.

Diakses pada 29 Desember 2020, dari

https://www.ifpi.org/ifpi-releases-music-

listening-2019/

Radio dBs 101,9 FM. (2013, 13 April). About

Radio dBs FM. Diakses pada 30 Desember

2020, dari www.dbs1019fm.com 